\title{
DAMPAK PEMBEKUAN PRODUK SAJADAH EKSTRA TERHADAP KONDISI SOSIAL EKONOMI NASABAH DI KSPPS BMT CSI SYARI'AH SEJAHTERA \\ Ade Fatonah ${ }^{1}$ \\ adhefatonah@gmail.com
}

\begin{abstract}
Investments become common thing done by the community as a form of financial management, with a variety of options that can be taken. In conventional economic management, the available investment is generally not according to sharia principles so that, as a Muslim, it becomes imperative to always be vigilant in investing so as not to get caught in an investment that contains ribawi elements.

The research method used is qualitative method, with the type of field research. To support the writing of this research, some data collection techniques that the author uses is the first interview of the customers. Secondly, the documentation informs the background of the freezing BMT CSI Syariah Sejahtera. Third, observation.

Based on the results of the study, the freezing of BMT CSI Syariah Sejahtera funds have social and economic impacts such as fear, severe and prolonged stress, lost of confidence as part of community members, loss of comfort when having to interact with environment, divorce, negative views of society, and crime. The economic impact that arises is the increase in unemployment rate, the increase of children who dropped out of school because the property is exhausted to cover the debts to third parties, the number of children who are malnourished because parents who can not provide adequate nutrition, bankruptcy because the business capital is invested to BMT and not return.
\end{abstract}

Keywords: investment, BMT, Customer CSI

\begin{abstract}
Abstrak
Investasi menjadihal yang lazimdilakukanolehmasyarakatsebagaibentukpengelolaanfinansial, denganberagampilihan yang bisadiambil. Dalam pengelolaan ekonomi konvensional, investasi yang tersedia umumnya tidak sesuai kaidah syariah sehingga, sebagai seorang Muslim menjadi suatu keharusan untuk selalu waspada dalam berinvestasi agar tidak terjebak dalam investasi yang mengandung unsur ribawi.

Metode penelitian yang digunakan adalah metode kualitatif, dengan jenis penelitian lapangan. Untuk mendukung penulisan penelitian ini, beberapa teknik pengumpulan data yangpenulis gunakan, adalah pertama wawancara para nasabah. Kedua, dokumentasiyang menginformasikan latar belakang pembekuanBMT CSI Syariah Sejahtera. Ketiga, observasi .

Berdasarkan hasil penelitian, pembekuan dana BMT CSI Syariah Sejahtera memiliki dampak sosial dan ekonomi seperti rasa takut, stress yang berat dan berkepanjangan, hilangnya kepercayaan diri sebagai bagian dari anggota masyarakat, hilangnya rasa nyaman ketika harus berinteraksi dengan lingkungannya, perceraian, timbul fitnah atau pandangan-pandangan negatif dari masyarakat, dan kriminalitas. Adapun dampak ekonomi yang timbul adalah bertambahnya tingkat pengangguran, bertambahnya anak yang putus sekolah karena harta bendanya habis untuk menutupi utang-utang kepada pihak ketiga, banyaknya anak yang kekurangan gizi karena orang tua yang tidak bisa memberi asupan gizi yang cukup,kebangkrutan karena modal usahanya diinvestasikan kepada BMT dan tidak kembali.
\end{abstract}

Kata Kunci: investasi, BMT, NasabahCSI

${ }^{1}$ Mahasiswa Pascasarjana IAIN Syekh Nurjati Cirebon 


\section{PENDAHULUAN}

\section{A. Latar Belakang}

Manusia sebagai makhluk sosial tidak dapat lepas untuk berhubungan dengan orang lain dalam rangka memenuhi kebutuhan hidupnya. Karena kebutuhan manusia sangat beragam dan terkadang tidak dapat memenuhi kehidupannya secara sendiri maka diperlukan adanya kerjasama dengan orang lain.

Hubungan untuk memenuhi kebutuhan dalam bekerjasama antara satu dengan lainnya harus adaaturan yang menjelaskan hak dan kewajiban untuk memberikan kewenangan masingmasing dalam menjalankan amanah yang telah mereka terima. Amanah yang mereka terima harus dijalankan dengan baik agar memberikan rasa aman pada pemberi amanah karena antara mereka akan mendapatkan manfaat dari kerjasama tersebut.

Menurut Syafii Antonio, Islam masih dianggap sebagai penghambat dalam melakukan sesuatu untuk kemajuan, masih dianggap sebagai sebuah ritual yang tidak ada hubungannya dengan aspek kehidupan ummat manusia. Padahal, Islam sesungguhnya memandang bahwa bumi dengan segala isinya merupakan amanah Allah SWT untuk dipergunakan sebaik-baiknya oleh ummat manusia bagi kesejahteraan bersama. ${ }^{2}$ Menurut Rahmat Syafii, Islam tidak memisahkan antara urusan dunia dan akhirat, sebab sekecil apapun perbuatan manusia harus didasarkan pada ketetapan Allah SWT. ${ }^{3}$

Islam, sebagai sebuah sistem, memberikan warna dalam setiap dimensi kehidupan ummat manusia, tak terkecuali pada bidang ekonomi. Dewasa ini, banyak bermunculan beberapa lembaga ekonomi yang kemudian berusaha untuk menerapkan prinsip syari'at Islam, misalnya berkaitan dengan larangan riba, prinsip- prinsip bagi hasil, zakat, dan lain-lain. ${ }^{4}$

Menurut at-Tariqi, sekalipun ada persamaan dengan sistem ekonomi lain, sistem ekonomi Islam memiliki perbedaan pandangan dengan yang lainnya. Hal ini terlihat dalam idealitas berbagai macam transaksi yang dilakukan. Aktivitas-aktivitas itu akan bernilai ibadah jika dilakukan sesuai dengan aturan yang sudah ditetapkan oleh Islam. ${ }^{5}$ Dalam hal ini, sesuai dengan firman Allah SWT yang berbunyi:

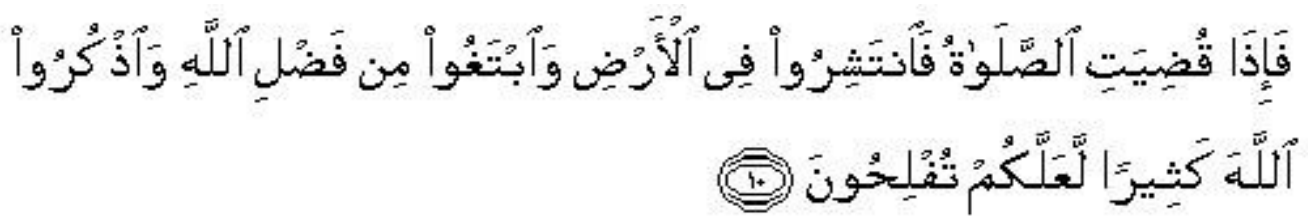

Artinya: "Apabila telah ditunaikan shalat, Maka bertebaranlah kamu di muka bumi; dan carilah karunia Allah dan ingatlah Allahbanyak- banyak supaya kamu beruntung". (QS. Al-Jumu'ah:10) ${ }^{6}$

\footnotetext{
${ }^{2}$ Muhammad Syafi'i Antonio, Bank Syariah dari Teori ke Praktik (Jakarta: Gema Insani, 2001), 3.

${ }^{3}$ Rachmat Syafi'i, Fiqih Muamalah(Bandung: CV. Pustaka Setia, 2001),10.

${ }^{4}$ Muhammad Syafi'i Antonio, Bank Syariah dari Teori ke Praktik (Jakarta: Gema Insani, 2001), 4.

${ }^{5}$ Abdullah Abdul Husain at-Tariqi, Ekonomi Islam: Prinsip, Dasar dan Tujuan (Yogyakarta: Magistra Insania Press, 2004), 110.

${ }^{6}$ Departemen Agama RI, Al-Qur"an dan Terjemahnya (Bandung: CV. Penerbit Diponegoro, 2008), 554.
} 
Dalam ayat di atas, dijelaskan bahwa Allah SWT telah memerintahkan umat manusia untuk mencari karunia-Nya, rezeki yang telah Allah persiapkan untuk semua makhluk, termasuk di dalamnya adalah umat manusia yang ada di muka bumi. Salah satu upaya yang dilakukan adalah dengan melakukan perencanaan khususnya berkaitan dengan masalah finansial secara matang agar menunjang keberlangsungan hidup di masa yang akan datang. ${ }^{7}$

Investasi menjadi hal yang lazim dilakukan oleh masyarakat sebagai bentuk pengelolaan finansial, tentu dengan beragam pilihan yang bisa diambil. Dalam pengelolaan ekonomi konvensional, investasi yang tersedia umumnya tidak sesuai kaidah syariah. Sehingga sebagai seorang Muslim dituntut untuk berhati-hati dalam berinvestasi agar tidak terjebak dalam investasi yang mengandung unsur ribawi.

Investasi pada hakikatnya merupakan penanaman modal yang dilakukan untuk proses produksi. Batasan syar'i dalam Islam tidak menjadikan sebuah kesulitan dalam pengelolaan finansial. Dalam Islam, upaya untuk memutar modal dalam kegiatan investasi yang mendatangkan return adalah aktivitas yang sangat dianjurkan.Islam mengembangkan mekanisme investasi bagi hasilyang dikaitkandengan masalah kapital dan keahlian. ${ }^{8}$

Sistem bisnis yang dijalankan berdasarkan prinsip ekonomi Islam telah mengalami pertumbuhan yang sangat pesat. Hal ini di pengaruhi oleh berbagai macam pemikiran dan diskusi serta pengkajian tentang ekonomi Islam. Lembaga keuangan syariah menjadi salah satu instrumen yang digunakan untuk menegakkan prinsip-prinsip ekonomi Islami. Lembaga keuangan syariah, sebagai bagian dari sistem ekonomi, menjadi bagian dari keseluruhan sistem sosial. Keberadaannya dipandang dalam keseluruhan konteks keberadaan ummat manusia(masyarakat), serta nilai-nilai yang terkandung dalamnya. ${ }^{9}$

Bisnis dengan menggunakan prinsip-prinsip syariah ditujukan dalam rangka memberikan sumbangsih positif bagi pencapaian tujuan sosio-ekonomi masyarakat yang lebih baik di masa yang akan datang. Bisnis secara syariah dijalankan dalam rangka menciptakan iklim bisnis yang baik dan terlepas dari berbagai bentuk praktek kecurangan. ${ }^{10}$

Dewasa ini, Indonesia memasuki era ekonomi Syariah yang ditandai dengan munculnya berbagai lembaga keuangan yang menggunakan prinsip berkeadilan dan bebas bunga. Prinsip ini tentu akan sangat berbeda dengan prinsip yang digunakan oleh lembaga keuangan nonsyariah. Sebagai gantinya, Islam mensyariatkan akad kerjasama mudharabah. Hal ini dilakukan untuk memudahkan masyarakat yang memiliki banyak harta namun tidak mampu mengelola keuangannya. Begitupun sebaliknya, bagi mereka yang tidak memiliki harta namun memiliki kemampuan dalam hal pengelolaan dan pengembangannya.

Faktor yang sangat berperan dalam perkembangan lembaga keuangan Syari'ah adalah ketertarikan masyarakat terhadap pola penyimpanan uang dalam bentuk investasi. Masyarakat tertarik mendepositkan dananya dengan harapan akan memperoleh keuntungan yang lebih

\footnotetext{
${ }^{7}$ Ibnu Katsir, TafsirIbnuKatsir (Bogor: Pustaka Imam Syafi'i, 2003), 35.

${ }^{8}$ Muhamad, Dasar-dasar Keuangan Islam (Yogyakarta: EKONISIA, 2004), 75

${ }^{9}$ Muhammad, Model-Model Akad Pembiayaan di Bank Syariah (Panduan Teknis Pembuatan Akad atau Perjanjian Pembiayaan pada Bank Syariah) (Yogyakarta: UII Press, 2009), 2.

${ }^{10}$ Muhammad, Model-Model Akad Pembiayaan di Bank Syariah (Panduan Teknis Pembuatan Akad atau Perjanjian Pembiayaan pada Bank Syariah) (Yogyakarta: UII Press, 2009), 2.
} 
besar. Beragam produk dan jasa dikeluarkan oleh lembaga keuangan Syari'ah untuk menghimpun dana dari masyarakat.

Baitul Maal wat Tamwil (BMT) sebagai penerima amanah dari nasabah melakukan pengelolaan dana secara baik, transparandisertai adanyakomunikasi antara pengurus dan nasabah. Keberhasilan sebuah lembaga keuangan bergantung pada semua pihak yang terlibat pada kerjasama dimaksud saat menjalankan amanah yang dititipkan oleh masyarakat. Seperti pada keterangan ayat dibawah ini:

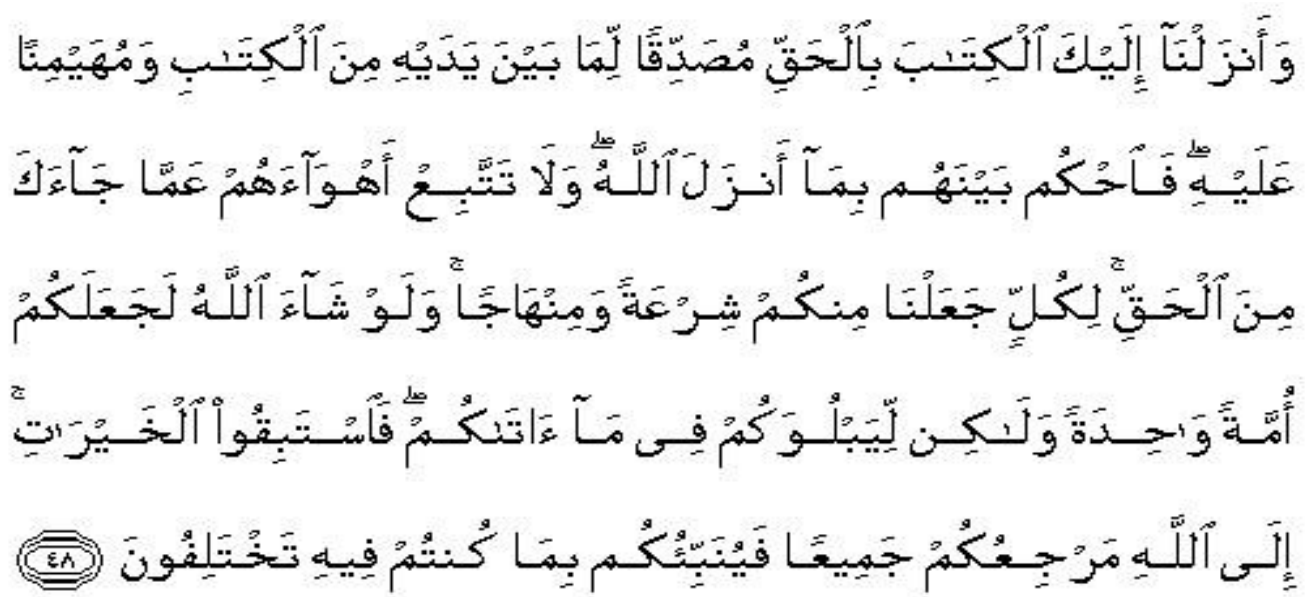

Artinya: "Dan kami Telah turunkan kepadamu Al Quran dengan membawa kebenaran, membenarkan apa yang sebelumnya, yaitu kitab-kitab (yang diturunkan sebelumnya) dan batu ujian terhadap kitab-kitab yang lain itu; Maka putuskanlah perkara mereka menurut apa yang Allah turunkan dan janganlah kamu mengikuti hawa nafsu mereka dengan meninggalkan kebenaran yang Telah datang kepadamu. untuk tiap-tiap umat diantara kamu, kami berikan aturan dan jalan yang terang. sekiranya Allah menghendaki, niscaya kamu dijadikan-Nya satu umat (saja), tetapi Allah hendak menguji kamu terhadap pemberian-Nya kepadamu, Maka berlomba-lombalah berbuat kebajikan. Hanya kepada Allah-lah kembali kamu semuanya, lalu diberitahukan-Nya kepadamu apa yang Telah kamu perselisihkan itu". ${ }^{11}$

Banyak orang tertarik untuk mendirikan usaha yang menerapkan prinsip Syariah atau menggunakan prinsip Islam. BMT berperan dalam menggerakkan roda perekonomian masyarakat. Nilai strategis BMT yang paling istimewa adalah terlihat pada perannya sebagai penggerak pembangunan. Menurut data Kementerian Koperasi RI hingga tahun 2015 setidaknya terdapat sekitar 4.500 BMT yang melayani 3,7 juta orang dengan aset diperkirakan mencapai 16 triliun rupiah dan dikelola oleh setidaknya 20 ribu orang. Dalam perkembangannya lembaga keuangan syari'ah, dikenal tiga institusi keuangan yang menggunakan istilah hampir sama, yaitu baitul maal, baitul tamwil, dan baitul mal watamwil. Dalam praktiknya, BMT mengembangkan usaha produktif dan investasi dalam meningkatkan kualitas kegiatan pengusaha kecil dengan mendorong kegiatan menabung dan menunjang pembiayaan ekonomi.

\footnotetext{
${ }^{11}$ Departemen Agama RI,Al-Qur"an dan Terjemahnya(Bandung: CV Penerbit Diponegoro, 2008), 150.
} 
Koperasi Simpan Pinjam Pembiayaan Syariah (KSPPS) Baitul Mal Wat Tamwil (BMT) PT. Cakrabuana Sukses Indonesia (CSI) Syariah Sejahtera, dalam aktanya sebagai salah satu lembaga keuangan syariah yang memiliki fungsi sebagai sebuah usaha komersil (tamwil), yaitu mencari keuntungan dengan melakukan penghimpunan dan pengelolaan dana dari masyarakat dalam bentuk jasa simpanan berdasarkan konsep syariah. Sebagai lembaga keuangan syari'ah produk-produk yang ditawarkan KSPPS BMT CSI Syariah Sejahteramerujuk pada ketentuanketentuan hukum Islam. Salah satunya adalah produk sajadah ekstra atau dalam bahasa lain di sebut sebagai simpan berjangka mudharabah dengan akad mudharabah mutlaqah.

Berdasarkan hasil observasi awal yang dilakukan peneliti, ditemukan data bahwa KSPPS BMT CSI Syariah Sejahteraadalah badan usaha koperasi berbasis Syariah didirikan dan dibentuk pada tahun 2014. Anggotanya ada yang berasal dari masyarakat Kabupaten Cirebon pada khususnya dan masyarakat Indonesia pada umumnya.

KSPPS BMT CSI Syariah Sejahtera menunjukkan perkembangan yang cukup pesat.BMT CSI telah membentuk cabang di seluruh Indonesia mulai dari Aceh hingga Papua. Namun, ternyata para nasabah dikejutkan oleh keputusan Otoritas Jasa Keuangan (OJK) yang menyatakan bahwa BMT CSI Syariah termasuk di dalamnya KSPSS BMT CSI Syariah Sejahtera telah melakukan usaha menghimpun dana masyarakat tanpa ijin.

Hasil observasi sementara yang dilakukan peneliti diperoleh data bahwa, lembaga dimaksud telah memenuhi unsur sebagai koperasi. Dalam prakteknya, secara formal penyertaan modal dalam koperasi dilakukan melalui akta perjanjian kerja sama penyertaan modal yang dilakukan di notaris atas dasar kesepakatan kedua belah pihak.Berdasarkan latar belakang di atas, penulis merasa tertarik untuk melakukan sebuah penelitian terhadap dampak pembekuan secara sosial ekonomi.

\section{B. Metode Penelitian}

Metode penelitian yang digunakan adalah metode kualitatif, dengan jenis penelitian lapangan (field research), yaitu peneliti terlibat langsung di dalam penelitian. Untuk mendukung penulisan penelitian ini, beberapa teknik pengumpulan data yang akan penulis gunakan, adalah pertama wawancara atau interview guna memperoleh informasi mendalam mengenai pemahaman dan wawasan serta respon pihak KSPPS BMT CSI Syariah Sejahtera maupun para nasabah. Kedua, dokumentasiyang menginformasikan latar belakang pembekuan produk sajadah ekstra di KSPPS BMT CSI Syariah Sejahtera. Ketiga, observasidilakukan untuk memperoleh data tentang dampak pembekuan produk sajadah ekstra terhadap kondisi sosial ekonomi nasabah di KSPPS BMT CSI Syariah Sejahtera. Adapun hal-hal yang di observasi adalah berkaitan dengan profil KSPPS BMT CSI Syariah Sejahtera dan latar belakang atau kondisi sosial ekonomi para nasabah KSPPS BMT CSI Syariah Sejahtera.

\section{PEMBAHASAN}




\section{A. Dampak Pembekuan BMT CSI terhadap Kondisi Sosial Nasabah}

Dewasa ini banyak BMT yang menawarkan berbagai bentuk pelayanan keuangan kepada calon nasabah. Pada perkembangannya, banyak BMT yang mengalami kegagalan dalam pengelolaannya sehingga harus dibekukan operasionalnya bahkan dilikuidasi, salah satunya adalah KSPPS BMT CSI Syariah Sejahtera.

Meskipun pertumbuhan BMT dari segi kuantitas cukup pesat namun dari segi kualitas sangat lambat. Tidak sedikit BMT yang gulung tikar karena kehabisan modal. Selain itu juga terdapat BMT yang gagal mengembalikan uang nasabah. Nasabah yang menjadi korban kebanyakan adalah masyarakat kecil. Kondisi ini mengakibatkan pembekuan pada Lembaga Keuangan Mikro tersebut.

Dalam Perbankan syari'ah terdapat Lembaga Penjamin Simpanan (LPS), dimana LPS itu berperan penting, apabila suatu bank syari'ah dilikuidasi dicabut izin operasi bank. Maka Lembaga Penjamin Simpanan yang menjamin uang para nasabah yang telah masuk atau berputar pada sistem perbankan tersebut.Problematika lain adalah tentang manejemen penjaminan simpanan. Jika dalam lembaga perbankan dana nasabah dijamin oleh Lembaga Penjamin Simpanan (LPS), sehingga ketika sebuah bank dilikuidasi dana nasabah aman. Namun dalam kasus BMT CSI tidak diketahui apakah mempunyai penjamin simpanan seperti pada perbankan syari'ah atau tidak.

Konsekuensi yang dapat diambil adalah setiap nasabah diharuskan memahami konsekuensi hukum terhadap BMT yang dibekukan. Perlindungan Hukum ini diberikan oleh hukum terkait pula dengan adanya hak dan kewajiban yang dimiliki oleh manusia sebagai subjek hukum. Perlindungan hukum yang bersifat represif ini sangat dibutuhkan dalam kehidupan manusia untuk menyelesaikan sengketa yang terjadi diantara para subjek hukum. Nasabah merupakan salah satu pelaku kegiatan perekonomian yang dapat juga dikatakan sebagai konsumen. Konsumen merupakan individu atau sekelompok orang yang mengkonsumsi suatu barang atau jasa yang disediakan oleh produsen. Konsumen sebagai pemakai barang atau jasa ini memerlukan suatu perlindungan hukum yang jelas dalam mendapatkan kepuasan serta kelayakan dalam mengkonsumsi barang atau jasa tersebut.

Otoritas Jasa Keuangan (OJK) melaporkan PT. CSI Group ke Bareskrim, pasalnya PT. CSI Group diduga melakukan investasi bodong dengan bunga yang menggiurkan bagi konsumen/nasabah di sejumlah daerah di Indonesia yang salah satunya di Cirebon, Jawa Barat. Setelah melakukan pelaporan kepada Bareskrim, Bareskrim memanggil petinggi dari PT. CSI Group untuk memberikan keterangan dan kesaksian, dan menahan dua orang petinggi PT. CSI Group. Bareskrim juga melakukan pemblokiran rekening PT. CSI Group sehingga membuat PT. CSI Group tidak dapat menjalankan koperasinya seperti biasanya.

Berdirinya PT. CSI Group ini telah membantu perekonomian masyarakat Indonesia khususnya masyarakat jawa barat dan Cirebon. Dengan modal awal sebesar Rp. 50.000.000,00 (lima puluh juta rupiah) para nasabah sudah dapat menikmati keuntungan bunga setiap bulannya sebesar 5\% atau paling sedikit Rp. 2.500.000,00 (dua juta lima ratus ribu rupiah). 
Memang ada anggapan bahwa KSPPS BMT CSI Syariah Sejahtera sangat membantu masyarakat khususnya nasabah dalam meningkatkan perekonomian. Setelah dibekukan para nasabahmenandatangani petisi yang di sampaikan kepada Presiden Republik Indonesiaberikut:

"Dengan hormat, saya adalah salah satu anggota dari KSPPS BMT CSI Syariah Sejahtera yang beranggotakan 15.964 orang yang menanggung hidup kurang lebih 60 ribu orang tersebar diseluruh Indonesia. Sekarang kami sedang mengalami penderitaan sehubungan dengan penahanan 2 orang pengurus koperasi kami oleh Bareskrim Mabes Polri, yang tidak saja telah mengganggu niat baik kami membantu pemerintah mensejahterakan masyarakat, tapi juga telah mencederai rasa keadilan kami selaku warga negara. Bahwa berkenaan dengan hal tersebut maka kami memohon dengan sangat bantuan Bapak Presiden untuk:

1. Membebaskan 2 orang pengurus koperasi kami karena beliau bukan Koruptor, bukan pembunuh dan bukan penjahat tapi beliau adalah Pahlawan Ekonomi buat kami.

2. Mendorong pihak terkait untuk mencabut pemblokiran dana anggota yang telah dilakukan oleh $\mathrm{BI}$ atas permintaan BARESKRIM.

Karena hal tersebut telah merugikan banyak orang, dalam hal ini anggota KSPPS BMT CSI Syariah Sejahtera di seluruh Indonesia.Demikian yang dapat kami sampaikan dan berharap penderitaan yang telah menimpa kami segera berakhir. Terima kasih atas segala perhatian dan bantuannya."

Dari problematika di atas, tentunya dapat dilihat bahwa dasarnya dengan adanya BMT tersebut masyarakat sangat menyambut baik, apalagi dengan jaminan-jaminan kesejahteraan yang ditawarkan BMT CSI kepada para nasabahnya. Ini terbukti hampir di semua kalangan sosial dari yang tingakat ekonomi menengah ke atas, bahkan tidak sedikit pula yang tingkat ekonomi rendah rela menyisihkan hartanya untuk bergabung menjadi anggota BMT tersebut.

Terjadinya hal yang tidak diinginkan pada perusahaan CSI, tentunya akan sangat berdampak sekali kepada segala aspek kehidupan terutama dari segi aspek sosial. Banyak pihak yang merasa sangat dirugikan terutama para pengurus serta para anggota yang terlibat dalam BMT CSI Syari'ah Sejahtera. Selain kesenjangan sosial, serta isu-isu yang terlontar dari masyarakat awam terhadap para nasabah CSI yang menjadi gunjingan-gunjingan negatif di lingkungan masyarakat sekitar dia berada. Hal ini tentunya membuat hidupnya menjadi tidak nyaman, interaksi-interaksi dengan lingkungan baik dengan tetangganya atau bahkan saudaranya sendiri menjadi kurang baik seakan-akan kepercayaan diri mereka hilang.

Berdasarkan hasil wawancara dengan Nasabah Ibu M, salah satu masyarakat sekitar yang tetangganya menjadi anggota CSI, menyatakan:

"Syukur saja CSI dibekukan, mereka pinginnya kaya mendadak tanpa usaha yang keras.

Sekarang baru tahu rasa uang mereka hilang apalagi sebagian dapat pinjem dari perbankan dan dari saudara-saudaranya" (Ibu M, Kalijaga, 02/09/2017).

Kata-kata yang dilontarkan pada jawaban salah satu responden tersebut, dapat disimpulkan bahwa pandangan-pandangan masyarakat menyikapi pembekuan CSI terutama KSPPS BMT CSI Syari'ah Sejahtera. 
Kemudian penulis mencoba mencari salah satu narasumber yang menjadi nasabah. Bapak D menyatakan:

“Dengan keadian CSI tentunya saya sangat dirugikan sekali, karena tidak sedikit uang saya yang merupakan tabungan saya untuk membuka usaha di masa pensiun, saya masukan ke CSI. Dengan dibekukannya CSI saya menjadi minder terhadap tetangga-tetangga saya, mau ngadain acara pernikahan saja saya takut dianggap pake uang nasabah". (Bapak D, Kalijaga, 03/09/2017)

Anggota dari KSPPS PT. CSI Syariah Sejahtera terdiri dari berbagai golongan masyarakat; masyarakat dengan tingkat ekonomi rendah, masyarakat tingkat ekonomi menengah dan masyarakat tingkat ekonomi atas. Ketiga tingkat ekonomi masyarakat tersebut sangat terbantu dengan adanya koperasi simpan pinjam pembiayaan syariah BMT PT. CSI Syariah Sejahtera yang dapat meningkatkan taraf hidup perekonomian mereka khususnya masyarakat tingkat ekonomi rendah. Banyak dari anggota KSPPS BMT PT. Cakrabuana Sukses Indonesia Syariah Sejahtera yang berprofesi sebagai petani, tukang beca, supir angkot dan pedagang yang bahumembahu untuk mengumpulkan modal setoran awal dan mereka membagikan bunganya secara merata, bahkan banyak juga dari pensiunan Pegawai Negeri Sipil yang menyimpan dana pensiunnya di koperasi simpan pinjam pembiayaan syariah Baitul Mal Wa Tamwil PT. Cakrabuana Sukses Indonesia Syariah Sejahtera.

Berdasarkan data yang diperoleh dari sejumlah informan yang penulis temui, diketahui bahwa rata-rata modal yang mereka investasikan di KSPPS BMT CSI Syariah Sejahtera cukup besar. Hal ini dikarenakan para nasabah juga mengharapkan keuntungan yang cukup besar pada setiap bulannya. Nasabah berinisial AJ misalnya, beliau menginvestasikan dananya sebesar Rp. 800.000.000,00(delapanratus juta rupiah) dengan asumsi bahwa setiap bulan akan mendapatkan keuntungan sebesar Rp. 40.000.000,00 (Empat Puluh Juta Rupiah). Modal tersebut didapatkan dengan melakukan pinjaman ke salah satu bank dan juga hasil dari menjual tanah yang ia miliki. Pekerjaan sebagai Pegawai Negeri Sipil membuatnya lebih mudah mengakses dana dari pihak ketiga untuk kemudian di investasikan di CSI. Begitupun dengan nasabah lainnya, dengan keuntungan $5 \%$ dari dana yang diinvestasikan membuat mereka bersemangat untuk menambah keuntungan yang lebih besar yang pada akhirnya mampu meningkatkan kesejahteraan keluarga khususnya. Hal ini sebagaimana diungkapkan oleh Nasabah N, salah satu nasabah dengan investasi Rp. 200.000.000,00 (Dua Ratus Juta Rupiah).

"Setelah masuk CSI, Alhamdulillah kesejahteraan keluarga kami semakin meningkat, setiap bulan kami mendapatkan keuntungan sebesar Rp. 10.000.000,00 (Sepuluh Juta Rupiah). Sebagai karyawan swasta, penghasilan sebesar ini sangat membantu dalam perekonomian keluarga kami". (Nasabah N, 12/09/2017)

Dari hasil wawancara dengan para informan polemik pembekuan yang terjadi pada CSI selain membawa dampak yang besar pada tataran sosial pastinya yang paling besar adalah dampak yang terasa dalam tataran perekonomian. Pada tingkat perekonomian yang rendah cenderung memaksakan dengan impian serta harapan yang besar dapat membuahkan hasil yang besar sesuai yang telah dijaminkan oleh sistem di perusahaan tersebut. 
Akibat pelaporan yang dilakukan oleh PT. Otoritas Jasa Keuangan terhadap KSPPS BMT PT. Cakrabuana Sukses Indonesia Syariah Sejahtera banyak masyarakat yang merasa dirugikan, dengan total kerugian yang mencapai Rp. 2.300.000.000,00 (dua triliun tiga ratus juta rupiah). Banyak nasabah/konsumen yang mengalami stress berat akibat pembekuan rekening PT. CSI Group karena mereka mengantungkan hidup kepada bunga yang diberikan dari KSPPS BMT PT. Cakrabuana Sukses Indonesia Syariah Sejahtera. Hal ini sebagaimana diungkapkan oleh nasabah berinisial AJ:

"Pembekuan CSI membuat saya stress karena banyak hutang yang harus kami bayar. Hutang-hutang itu hasil dari pinjaman dan yang saya investasikan di CSI". (AJ/12/09/2017)

Dampak yang terjadi setelah proses pembekuan adalah kehidupan nasabah yang semula serba ada karena keuntungan yang diperoleh dari CSI, setelah adanya pembekuan menjadi terkatung-katung tanpa adanya kepastian. Sebagaimana diketahui, AJ adalah nasabah yang telah menginvestasikan dananya sebesar Rp. 800.000.000,00 yang ia peroleh dengan melakukan pinjaman kepada pihak ketiga. Keuntungan dari prosentase yang didapat dari investasi di PT. CSI digunakan sebagian untuk mencicil pinjaman. Setelah adanya pembekuan ini, beliau tidak mampu lagi melakukan pembayaran terhadap pihak ketiga yang pada akhirnya beberapa set yang ia miliki menjadi barang sitaan pihak ketiga. Berdasarkan fenomena dimaksud, secara umum hal ini berakibat pada melemahnya perekonomian keluarga nasabah khususnya dan masyarakat luas secara umum.

Berdasarkan beberapa hasil wawancara di atas dapat disimpulkan, pembekuan CSI khususnya BMT CSI Syariah Sejahtera memberikan pengaruh dan dampak yang besar terhadap kondisi sosial masyarakat. Hal ini dibuktikan dengan banyaknya pandangan-pandangan negatif dari masyarakat awam terhadap para korban pembekuan yang berakibat secara psikologis pada semua nasabah yang menjadi korban atas dibekukannya CSI tersebut.

Sehubungan hal tersebut, maka perlu dinetralisir agar konflik sosial tidak semakin berlanjut. Tentunya dengan adanya perlindungan hukum dari pihak yang berwenang serta pengarahan-pengarahan dari pemerintah, tokoh masayarakat, dan para pemuka agama. Sebagaimana yang tertera pada Undang-Undang Perlindungan konsumen Nomor 8 Tahun 1999 Pasal 1 butir 1 memberi pengertian yang meliputi "Segala upaya yang menjamin adanya kepastian hukum untuk memberi perlindungan kepada konsumen". Dalam hal ini maka dalam segala pemakaian produk atau jasa oleh konsumen, konsumen berhak mendapat suatu kepastian hukum. Dalam pasal 2 Undang-Undang Nomor 8 Tahun 1999 tentang perlindungan konsumen yang membahas tentang asas perlindungan konsumen menyebutkan bahwa perlindungan konsumen berdasarkan manfaat, keadilan, keseimbangan, keamanan, dan keselamatan. Dalam hal ini segala aspek sangat berperan penting agar dapat terlaksana secara maksimal. 


\section{B. Analisis Dampak Pembekuan BMT CSIterhadap Kondisi Sosial Ekonomi Nasabah}

Koperasi Simpan Pinjam Pembiayaan Syariah Baitul Mal Wa Tamwil PT. Cakrabuana Sukses Indonesia Syariah Sejahtera adalah badan usaha koperasi berbasis syariah didirikan dan dibentuk pada tahun 2014 oleh masyarakat Kabupaten Cirebon pada khususnya dan masyarakat Indonesia pada umunya. KSPPSBMT PT. CSI Syariah Sejahtera telah memiliki jumlah anggota sekitar 16.000-an dan memiliki kantor layanan dan cabang yang tersebar di berbagai daerah di Indonesia.

Otoritas Jasa Keuangan (OJK) dan Satuan Tugas Penanganan Dugaan Tindakan Melawan Hukum di Bidang Penghimpunan Dana Masyarakat dan Pengelolaan Investasi (Satgas Waspada Investasi) menetapkan tiga perusahaan investasi ilegal.

Ketua Satgas Waspada Investasi Tongam Lumban Tobing menyebutkan, tiga perusahaan tersebut adalah PT Cakrabuana Sukses Indonesia (PT CSI) dan Dream For Freedom dan United Nations Swissindo World Trust International Orbit (UN Swissindo). "OJK dan Satgas Waspada Investasi menyatakan, ketiga ini sebagai kegiatan yang melanggar hukum atau ilegal," kata Tongam, di Kantor OJK, Jakarta, Selasa (1/11/2016). ${ }^{12}$

Dalam menjalankan kegiatan, CSI telah mampu mengumpulkan dana dari masyarakat sebesar Rp 2 triliun. Dana tersebut berasal dari 7 ribu peserta. Modus yang dijalankan oleh CSI adalah dengan membentuk koperasi kemudian menghimpun dana dengan penawaran bunga di atas bunga bank atau mencapai 5 persen. Dalam mengumpulkandana dari masyarakat ini, CSI tidak memiliki izin usaha dari otoritas manapun. Dengan alasan itulah maka CSI akhirnya dibekukan.

Adanya kasus pembekuan terhadap KSPPS BMT CSI Syariah Sejahtera berdampak sistemik pada kondisi sosial ekonomi nasabah. Nasabah berbondong-bondong turun ke jalan menuntut uang investasinya dikembalikan. Namun ada sebagian yang hanya pasrah menerima nasib yang telah terjadi dengan menerima segala macam resikonya.

Pada kasus CSI dengan pembekuan tersebut jelaslah membawa dampak yang sangat besar dan menjadi faktor pendukung dari kesenjangan baik dari sosial maupun ekonomi khususnya bagi para nasabah umumnya bagi para masyarakat luas. Seperti timbulnya pandangan-pandangan negatif dari masyarakat-masyarakat yang perekonomiannya rendah ataupun dari masyarakat awam terhadap para nasabah walaupun pada dasarnya mereka adalah korban.

Selanjutnya dari pihak-pihak korban sendiri yang terlibat secara langsung maupun tidak langsung dalam kegiatan perusahaan tersebut merasakan dampak yang sama baik secara ekonomi maupun sosial. Secara ekonomi tentulah meraka akan kehilangan sejumlah uang dengan nominal yang tentunya tidak sedikit, yang mereka dapatkan dari hasil menabung sejak lama atau mungkin hasil meminjam dari bank serta pihak-pihak ketiga. Dari hal tersebut tidak sedikit harta para nasabah dijadikan jaminan dengan cara disita ataupun dijual untuk menutupi

\footnotetext{
12 “Web Page,” accessed September 27, 2017, (http://bisnis.liputan6.com/read/2640477/ojk-nyatakan-3-perusahaaninvestasi-ini-ilegal.
} 
utang-utang yang dipinjam tersebut. Jelaslah kemiskinan di masyarakat akan semakin meningkat.

Sosial ekonomi adalah posisi seseorang dalam masyarakat berkaitan dengan orang lain dalam arti lingkungan pergaulan, prestasinya, dan hak-hak serta kewajibannya dalam hubungannya dengan sumber daya. ${ }^{13}$ Menurut Abdul Syani sosial ekonomi adalah kedudukan atau posisiseseorang dalam kelompok manusia yang ditentukan oleh jenis aktivitas ekonomi, pendapatan, tingkat pendidikan, jenis rumah tempat tinggal, dan jabatan dalam organisasi. ${ }^{14}$

Dari hasil wawancara pun jelaslah dampak sosial yang dirasakan oleh para nasabah. Timbulnya ketidaknyamanan karena menjadi bahan pembicaraan orang-orang di sekitarnya, rasa takut yang timbul karena dikejar-kejar utang, perceraian, interaksi dan komunikasi yang tertutup dan terbatas dengan pihak luar dan dampak-dampak sosial psikologis lainnya.

Dalam penelitian ini dampak pada kasus pembekuan BMT CSI Syariah Sejahtera dapat disimpulkanmenjadi 2 (dua)bidang yang terpengaruh yaitu secara ekonomi dan sosial.

\section{Dampak Sosial}

Dampak sosial yang timbul karena pembekuan BMT CSI Syariah Sejahtera diantaranya:

a. Rasa takut

b. Stress. Stress yang berat dan berkepanjangan dapat menimbulkan gangguan jiwa.

c. Hilangnya kepercayaan diri sebagai bagian dari anggota masyarakat.

d. Hilangnya rasa nyaman ketika harus berinteraksi dengan lingkungannya.

e. Perceraian.

f. Timbul Fitnah atau pandangan-pandangan negatif dari masyarakat.

g. Kriminalitas.

\section{Dampak Ekonomi}

Dampak ekonomi yang timbul karena pembekuan BMT CSI Syariah Sejahtera diantaranya:

a. Bertambahnya tingkat pengangguran. Orang yang mengandalkan hasil dari BMT tanpa mempunyai pekerjaan lain, setelah dibekukan otomatis akan diberhentikan dan timbulah pengannguran

b. Bertambahnya anak yang putus sekolah. Hal ini terjadi karena harta bendanya habis untuk menutupi utang-utang kepada pihak ketiga yang digunakan untuk berinvestasi pada perusahaan tersebut.

c. Banyaknya anak yang kekurangan gizi. Hal ini terjadi orang tua yang tidak bisa memberi asupan gizi yang cukup karena keterbatasan ekonomi setelah dibekukannya CSI.

d. Bangkrut. Ini terjadi karena modal usahanya diinvestasikan kepada BMT dan tidak kembali.

Sebagaimana juga yangtertera laporan PBB I berjudul Report on International Definition andMeasurement of Standart and Level Living, badan dunia tersebut menetapkan 12 jenis komponen yang harus digunakan sebagai dasar untuk memperkirakan kebutuhan manusia,

\footnotetext{
${ }^{13}$ Soerjono Soekanto,Sosiologi Suatu Pengantar(Jakarta: PT.Raja Grafindo, 2007), 253.

${ }^{14}$ Abdul Syani, Sosiologi Skematika, Teori, dan Terapannya(Jakarta: Bumi Aksara, 2012), 75.
} 
meliputi: ${ }^{15}$ Kesehatan, Makanan dan gizi, Kondisi pekerjaan, Situasi kesempatan kerja, Konsumsi dan tata hubungan aggregative, Pengangkutan, Perumahan, termasuk fasilitas-fasilitas perumahan, Sandang, Rekreasi dan hiburan, Jaminan sosial; danKebebasan manusia.

Berdasarkan masalah-masalah tersebut maka sejatinya harus segera dicari solusinya. Di sini peran penting pemerintah serta para pihak berwenang untuk mengembalikan situasi menjadi lebih baik. Solusi-solusi yang ditawarkan terhadap penyelesaian kasus sengketa haruslah berdasarkan undang-undang perlindungan konsumen serta dilihat dari berbagai aspek kehidupan agar tidak terkesan memihak sehingga hanya menguntungkan salah satu pihak. Selain itu pemahaman masyarakat harus diluruskan kembali dan kepada para korban harus dicarikan jalan solusinya sehingga dampak-dampak secara sosial dan ekonomi dari pembekuan tersebut tidak semakin memburuk.

\section{Perlindungan Hukum Bagi Nasabah}

Perlindungan hukum bagi nasabah BMT yang berpatokan pada asas manfaat sesuai dengan UU Nomor 8 tahun 1999 ini sangat penting untuk menjamin bagi nasabah BMT memperoleh haknya. Asas manfaat ini adalah menempatkan pihak produsen maupun konsumen memiliki kedudukan yang sama sehingga tidak ada kerugian dari masing-masing pihak baik nasabah maupun BMT dan masing-masing pihak dapat memperoleh haknya. Asas keseimbangan juga diperlukan dalam perlindungan hukum nasabah BMT, yaitu adanya keseimbangan antara pelaku usaha, nasabah, serta pemerintah sehingga dapat terwujud sistem lembaga keuangan mikro yang baik dan stabil. Asas penting lainnya adalah asas kepastian hukum yaitu asas yang membuat para pelaku usaha maupun konsumen dapat mematuhi peraturan yang berlaku sehingga tidak akan melanggar hukum yang telah diatur.

Dengan adanya kepastian hukum ini nasabah dapat menggunakan jasa dan produk BMT dengan rasa aman dan dapat menjadi suatu jaminan apabila terjadi suatu hal yang tidak diinginkan dalam penggunaan produk dan jasa tersebut. Apabila BMT itu dibekukan maka nasabah masih dapat merasa aman apabila sudah terdapat kepastian hukum.

Perlindungan hukum bagi nasabah menjadi urgen karena secara nyata kedudukan antara para pihak BMT dan nasabahnya seringkali tidak seimbang. Ditengah maraknya kasus yang berhubungan dengan pembekuan BMT saat ini sehingga memunculkan kekhawatiran bagi para nasabah terhadap uang mereka yang disimpan dan berputar pada BMT, terutama ketika lembaga ini dibekukan.

Perlindungan hukum ini diperlukan bagi nasabah untuk memberikan rasa aman kepada nasabah yang ingin dan sudah bergabung dengan Lembaga Keuangan Mikro (LKM), terutama yang berbentuk BMT. Tidak sedikit dari mereka yang berasal dari ekomi rendah bergabung untuk mengembangkan usaha mikronya. Sebagai nasabah BMT, mereka harus mendapat perlindungan hukum dari perilaku orang-orang yang tak bertanggung jawab. Oleh karena itu perlu adanya komunikasi yang baik serta materi hukum, struktur hukum, dan kesadaran hukum bagi para pelaku lembaga keuangan mikro seperti BMT. Pada akhrinya, sebuah Lemba

\footnotetext{
${ }^{15}$ Matias Siagian, Kemiskinan dan Solusi(Medan: PT.Grasindo Monoratama), 74.
} 
Keuangan Mikro dapat berjalan dengan baik dan seimbang tanpa harus ada yang dirugikan salah satu pihaknya.

Perlindungan hukum ini sangat penting untuk memberikan kepastianhukum terhadap nasabah BMT agar para nasabah ini mempunyaikepastian hukum yang jelas dan tidak diombang-ambingkan denganpermasalahan yang berhubungan dengan sistem operasional BMT. Parapenegak hukum harus menindak lanjuti persoalan yang terjadi antaranasabah dengan pengurus melalui prosedur yang telah diatur diatur dalam Undang-undang. Apabila setiap orang mempunyai kesadaranhukum untuk mematuhi segala prosedur yang telah diatur dalamundang-undang, maka masyarakatakan mempunyai kepercayaan yangtinggi terhadap lembaga keuangan mikro BMT karena mendapatkankepastian perlindungan hukum.

Perlindungan hukum yang jelas bagi nasabah BMT dapat dijadikanpijakan untuk ke arah mana sengketa ini dapat diselesaikan. MengingatBMT atau Lembaga Keuangan Mikro lainnya belum memiliki aturantentang Lembaga Penjamin Simpanan yang khusus untuk LKM, maka perlindunganhukumbagi para nasabah ini memang seharusnyamenjadi suatu hal yang bersifat mutlak bagi lembaga keuangan.

Padadasarnya antara LKM BMT dengan nasabah BMT yang menyimpankandananya adalah saling berkaitan satu sama lain. Di satu pihak nasabahingin dana yang dititipkan dapat berkembang dan aman saat dititipkan,sedangkan di sisi lain BMT mengharap banyak masyarakat menitipkanuangnya dan menyimpan dananya pada BMT untuk disalurkan melaluiproduk-produk BMT. Perlindungan hukum ini dibutuhkan juga baginasabah untuk memberikan jaminan terhadap uang nasabah yang sudahdititipkan di BMT, baik jaminan dari segi kemanfaatan, pengelolaandan aspek syari'ahnya.

Bentuk Perlindungan hukum bagi nasabah BMT yang dibekukandi Indonesia dapat menggunakan Undang-undang Nomor 1 Tahun 2013tentang Perlindungan hukum bagi pengguna jasa LKM, khususnyapasal 24, 25, dan 26. Pasal 24 dan 25 digunakan sebagai pencegahanterjadinya sengketa atau pencabutan izin, sedangkan pada pasal 26 inidigunakan sebagai pelayanan pengaduan penyimpan apabila nasabahmengalami kerugian atau tidak terpenuhi hak-haknya. Apabila BMTberbadan hukum koperasi maka perlindungan hukum bagi nasabahnyamenggunakan Undang-Undang Nomor 25 Tahun 1992, khususnya pasal54 tentang penyelesaian.

\section{PENUTUP}

Dampak sosial yang timbul karena pembekuan BMT CSI Syariah Sejahtera diantaranya: rasa takut, stres yang berat dan berkepanjangan dapat menimbulkan gangguan jiwa, hilangnya kepercayaan diri sebagai bagian dari anggota masyarakat, hilangnya rasa nyaman ketika harus berinteraksi dengan lingkungannya, perceraian, timbul fitnah atau pandangan-pandangan negatif dari masyarakat, dan kriminalitas.

Adapun dampak ekonomi yang timbul karena pembekuan BMT CSI Syariah Sejahtera diantaranya: Bertambahnya tingkat pengangguran, bertambahnya anak yang putus sekolah, banyaknya anak yang kekurangan gizi, dan bangkrut. 
Berdasarkan masalah-masalah tersebut maka sejatinya harus segera dicari solusinya. Di sini peran penting pemerintah serta para pihak berwenang untuk mengembalikan situasi menjadi lebih baik. Solusi-solusi yang ditawarkan terhadap penyelesaian kasus sengketa haruslah berdasarkan undang-undang perlindungan konsumen serta dilihat dari berbagai aspek kehidupan agar tidak terkesan memihak sehingga hanya menguntungkan salah satu pihak. Selain itu pemahaman masyarakat harus diluruskan kembali dan kepada para korban harus dicarikan jalan solusinya sehingga dampak-dampak sbaik secara sosial dan ekonomi dari pembekuan tersebut tidak semakin memburuk.

\section{DAFTAR PUSTAKA}

Antonio, Muhammad Syafi'i. Bank Syariah dari Teori ke Praktik. Jakarta: Gema Insani, 2001.

at-Tariqi, Abdullah Abdul Husain.Ekonomi Islam: Prinsip, Dasar dan Tujuan. Yogyakarta: Magistra Insania Press, 2004.

Departemen Agama RI. Al-Qur'an dan Terjemahnya. Bandung: CV. Penerbit Diponegoro, 2008.

Katsir, Ibnu. Tafsir Ibnu Katsir. Bogor: Pustaka Imam Syafi'i, 2003.

Muhamad. Dasar-dasar Keuangan Islam. Yogyakarta: EKONISIA, 2004.

Muhammad. Model-Model Akad Pembiayaan di Bank Syariah (Panduan Teknis Pembuatan Akad atau Perjanjian Pembiayaan pada Bank Syariah). Yogyakarta: UII Press, 2009.

Siagian, Matias.Kemiskinan dan Solusi. Medan: PT.Grasindo Monoratama.

Soekanto, Soerjono. Sosiologi Suatu Pengantar. Jakarta: PT.Raja Grafindo, 2007.

Syafi'i, Rachmat. Fiqih Muamalah. Bandung: CV. Pustaka Setia, 2001.

Syani, Abdul. Sosiologi Skematika, Teori dan Terapannya. Jakarta: Bumi Aksara, 2012.

"Web Page," accessed September 27, 2017. (http://bisnis.liputan6.com/read/2640477/ojknyatakan-3-perusahaan-investasi-ini-ilegal. 